\title{
Pillars of Sustainable Development
}

\author{
Fariba Azabdaftari* \\ Department of Basic Sciences, Medical Sciences University of Tabriz, Iran
}

Submission: September 04, 2019; Published: October 09, 2019

"Corresponding author: Fariba Azabdaftari, Faculty Member of English Education, Department of Basic Sciences, Medical Sciences University of Tabriz, Tabriz, Iran

Keywords: Development; Business; Human organizations

\section{Opinion}

As the octopus of business is spreading its long and powerful legs all over the world, hesitations are growing around the nature and functions of human organizations. During the last decades a widespread feeling has emerged for an urgent need for essential transformation in the ways of management of today. Several seminars have been held offering a great variety of business consultants and ideas in this regard. However, with corporations thriving to be more powerful than ever, and the business, which is obviously dominating politics, why should have all these efforts be done to impose a change in fundamentals of such a prosper management?

Approaching the issue from another angle, a different picture is coming to the sight. Top executives are under enormous and constant stress today. Working very long hours and not being able to maintain a personal and rather healthy relationship exhausts them gradually. Despite significant material prosperity, they take little joy and satisfaction in their lives. They feel entirely powerless, insecure and even miserable encountering the global market that constantly pushes them around the corner, the market that often its spirals are neither predictable nor even comprehendible.

Rapidly changing regulations in market, increasingly merging of little companies into gigantic corporations and stunning cultural and structural changes imposed continuously in the mood of running the business, go beyond learning and adapting capabilities of even the strongest and most talented individuals. The consequences emerge as a deep and disappointing feeling among managers. They conclude that no matter how hard they work; things will never come under control [1].

The complexity that has become one of most dominant characteristics of our industrial society seems to be the root cause of this deep misery among business executives of today. At the beginning of the 21th century, we find ourselves surrounded by massively complex systems. These systems interfere with almost every aspect of our lives and directly or indirectly order us what to do or what not to do. The complexities such as immediate worldwide communication through sophisticated electronic networks and automated factories that people face in amazement, and yet cannot comprehend the role they play in running the giant multinational organizations and the worldwide global trading maintains them in an enduring state of confusion all the time [2].

Despite hailing these complex systems for their incredible sophistication, there is an increasing recognition that the present business and organizational environment are very different from traditional management both in theory and practice. If even not everybody accepts it as an alarming sign, there has been an increasing concern that the present organizational and technological systems can be the primary driving force of global environmental destruction, and a serious threat to the long-term survival of humanity. Considering environmental, social, and economic or trade factors as three distinct and yet interconnected pillars of sustainable development, we need to initiate a planning of different nature in many of our technologies and social organizations to fill the wide gap between the human needs which are in harmony with the ecologically sustainable systems of nature and the trend of the business of the era.

\section{References}

1. Capra F (2002) The hidden connections. Doubleday, New York, USA.

2. Mensah J, Ricart CS (2019) Sustainable development: Meaning, History, Pillars and Implications for Human Action: Litertur Review. Taylor and France Groups, UK. 


\begin{tabular}{|l|}
\hline \multicolumn{1}{|c|}{ Your next submission with Juniper Publishers } \\
will reach you the below assets \\
- Quality Editorial service \\
- Swift Peer Review \\
- Reprints availability \\
- E-prints Service \\
- Manuscript Podcast for convenient understanding \\
- Global attainment for your research \\
- Manuscript accessibility in different formats \\
( Pdf, E-pub, Full Text, Audio) \\
- Unceasing customer service \\
Track the below URL for one-step submission \\
https://juniperpublishers.com/online-submission.php \\
\hline
\end{tabular}

